\title{
A SURVEY OF THE VEGETATTON \\ OF JEWEL CAVE NATIONAL MONUMENT
}

\author{
Hollis Marriott \\ Ronald L. Hartman \\ Department of Botany \\ University of Wyoming \\ Laramie
}

\section{Objectives}

Jewel Cave National Monument (hence referred to as JECA) occupies 516 ha on the southwestern edge of the Limestone Plateau area of the Black Hills (Custer Co., South Dakota). Underlain by the resistant Pahasapa limestone (Mississippian), it is characterized by steep topography and deep canyons, with elevations ranging from roughly 1550 to $1750 \mathrm{~m}$ above sea level. Ponderosa pine forest dominates the landscape. Much of the forest was logged at least once prior to being incorporated into the Monument during a US Forest Service-National Park Service land swap in the early 1960's. Roughly one quarter section (the "old area") was part of the original Monument and has not been logged.

Prior to 1985, studies of the vegetation and flora at JECA were limited to small projects by seasonal staff; this project was carried out to satisfy the need for more thorough baseline information. The primary objectives were two: to compile a flora (a list of vascular plants) of JECA, and to map plant communities present at the time of the study. As well as serving as a baseline for resource management, this information will be useful for above-ground interpretation. Other benefits from the project include an herbarium for the Monument, a wildflower checklist for visitor use, and several specific recommendations for management of the Monument's vegetation and flora.

\section{Methods}

The Flora Collecting began in early May and continued through early September, 1985. Specimens were pressed and dried, and habitat information was recorded for each. All specimens were identified at the Rocky Mountain Herbarium, University of Wyoming (hence referred to as the RM). Collection data were entered into a microcomputer database from which checklists and herbarium labels were generated. Specimens were mounted and placed in the Monument herbarium, with duplicates on file at the RM. Specimens collected by previous workers at JECA were examined, and annotated and remounted when necessary.

Abnormally low rainfall hampered floristic work. Normally-common species were rare or absent, and many individuals were dwarfed and did not flower. However, specimens already in the Monument herbarium (175 taxa) helped compensate for 
poor collecting conditions.

The Vegetation As a first step in vegetation mapping, vegetation units were delimited on an aerial photograph and modified through ground reconnaisance without sampling. Quantitative analysis was carried out in August. Three stands (when available) of each plant community type were sampled using quadrats located according to a stratified random design. Depending on the size of the stand, 10 to 20 quadrats were sampled. Nested quadrats of $50 \mathrm{sq} \mathrm{m,} 12.5 \mathrm{sq} \mathrm{m}$, and 200 sq $\mathrm{cm}$ were used to sample trees, shrubs and herbs respectively. Circumference at breast height was recorded for trees (at least $40 \mathrm{~cm}$ in circumference) and saplings (at least $1 \mathrm{~m}$ tall) were counted by species. Cover class was noted for shrub species, and presence/absence was recorded for herbaceous taxa. Cover class was recorded for the entire herbaceious component as well.

Forest communities were characterized using basal area of the tree component, tree density, average $\mathrm{DBH}$, sapling density and dominant shrub/herb associates. Grassland and shrubland communities were classified based on dominant species as determined by frequency of occurrence. Drought conditions had little effect on vegetation sampling due to the predominance of forest/shrub associations in the Monument. Grassland dominants were easily recognized from dead material from the previous year.

In addition to quantitatively-characterized plant communities, communities too limited in extent to be sampled are included on the vegetation map. The locations of noxious weeds also are marked. An overlay of soil units accompanies the map (soils information was obtained from the Soil Conservation Service in Custer). No useful information, either written or oral, concerning logging patterns in the Monument was found. Presence/absence of large stumps (from timber harvest) and small stumps (from thinning) was noted for each quadrat in hopes of obtaining some insight into logging history.

\section{Results}

The Flora Considering that most of JECA is forested with ponderosa pine, the flora is surprisingly diverse, consisting of 393 taxa in 65 families. Much of the diversity is attributable to plant communities of limited extent, such as grasslands, deciduous woodlands in canyon bottoms (birch, aspen and boxelder) and palustrine com munities around springs and seeps. The flora includes six taxa listed as rare in South Dakota by the South Dakota Natural Heritage Program (Hautcooper et al. 1985).

Forty-eight species at JECA are known to be exotic (introduced); of these, leafy spurge (Euphorbia esula), Canada thistle (Cirsium arvense) and field bindweed (Convolvulus arvensis) are considered noxious weeds in custer Co. Leafy spurge is locally common at Chokecherry Spring; individuals are occasionally found elsewhere. Canada thistle is scattered throughout the Monument near springs, seeps and culverts. Field bindweed occurs around the Visitor Center parking lot and sporadically on other disturbed sites. 
The Vegetation JECA is extensively forested with ponderosa pine (Pinus ponderosa). Four pine associations were recognized.

The ponderosa pine-ninebark association is restricted to steep north-facing slopes. It is characterized by dense stands of relatively small pine trees. Sapling density is very high and stands of doghair are common. Ninebark (Physocarpus monogynous) dominates the understory, often to the exclusion of other species. Herbaceous groundcover is sparse to absent. At JECA the ponderosa pine-ninebark association correlates well with Vanocker soils, which are alfisols with very thin $\mathrm{E}$ horizons suggestive of relatively recent development (see discussion in Conclusions).

The ponderosa pine-snowberry association occurs on east- and west-facing slopes, gentle south-facing slopes and on near level upland topography such as ridgetops and benches. It intergrades with the ponderosa pine-little bluestem association. Stands are closed to somewhat open with relatively large individual trees. Doghair stands are common, but overall, saplings are less dense than in the ponderosa pine-ninebark association. The dominant understory species is snowberry (Symophoricarpos sp.*). Herbaceous groundcover ranges from absent to almost complete in areas transitional to ponderosa pine-little bluestem and grassland communities. Grassy openings are common. This community occurs on Vanocker, Sawdust and Paunsagunt soils, and is more strongly correlated with slope and aspect than soil type.

The ponderosa pine-little bluestem association characteristically consists of somewhat open to very open stands of pine with relatively large individual trees. Sapling densities are low although doghair stands do occur. Little bluestem (Andropogon scoparius) is the dominant understory species, and skunkbush (Rhus trilobata) is the most frequently encountered shrub. This association correlates well with the Sawdust soil, an entisol characteristic of steep south-facing slopes. The occurrence of entisols under forest vegetation in the JECA area has suggested that these sites have not been forested long enough for the development of alfisols (D. Hoeft pers. comm.).

The ponderosa pine-gooseberry association is represented by only one mappable stand, in the bottom of Hell Canyon. The stand is closed and contains moderately large trees. Sapling density is low. Gooseberry (Ribes oxyacanthoides) is the most frequent associate, but chokecherry (Prunus virginiana) and common juniper (Juniperus communis) also are common.

The unlogged portion of JECA (the old area) is vegetated mainly with ponderosa pine-snowberry forest. It differs from corresponding stands in the remainder of

*It is not clear whether this is Symphoricarpos albus or S. occidentalis (which are differentiated by flower morphology) because snowbery did not bloom on upland sites due to drought conditions. Pinus ponderosa-S. occidentalis is a very common pine association in the Black Hills (Thilenius 1971), suggesting that the

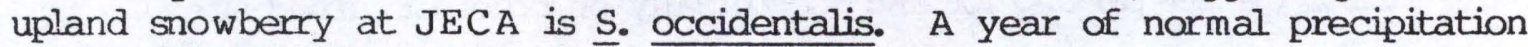
should resolve the problem. 
the Monument in that trees average larger and sapling density is much higher. However, the old area probably is not extensive enough for comparisons to be valid. Cut stumps were found in all forest stands except those in the old area. Most were well on the way to decomposition (as determined by the kick test), making it impossible to determine relative age.

Two grassland types occur at JECA. The western wheatgrass-blue grama association is best developed on the alluvial Cordeston-Winetti soil complex in the bottom of Hell Canyon near its confluence with Lithograph Canyon. This community also occurs on gentle topography in openings in ponderosa pine-snowberry forest. On steeper slopes and ridgetops, little bluestem is dominant. Both western wheatgrass-blue grama and little bluestem com munities show evidence of pine invasion in the form of ponderosa pine saplings and seedlings.

Shrublands are uncommon at JECA. Snowberry (Symphoricarpos albus) thickets occur in the bottoms of canyons. Mountain mahogany (Cercocarpus montanus), which is abundant on the Minnekahta limestone less than $35 \mathrm{~km}$ to the west, occurs only sporadically.

\section{Conclusions}

JECA is vegetated predominantly with ponderosa pine forest, but the occurrence of small stands of other communities contributes to a surprising diversity of plant life (393 taxa in 516 ha). Resource management should be aimed at preserving this diversity, as well as at maintaining ponderosa pine communities in their natural states.

Because many of the plant communities and corresponding species at JECA occur only in one to several sites of limited extent, care should be taken to protect these sites from disturbance. Such sites include springs and seeps, grasslands in the bottom of Hell Canyon, the canyon bottom and adjacent lower north-facing slope along the north boundary and canyon and ravine bottoms in general. Grazing is a threat at this time, for the Monument is not completely fenced off from surrounding lands. Cattle occasionally escape from nearby USFS allotments and enter the Monument. During August, 1985, a small (probabily less than 20 head) herd remained in the Hell Canyon area for several weeks. During that time, the grassland vegetation was cropped to near ground level and the vegetation around Prairie Dog Spring was heavily grazed and trampled. Construction of a fence to keep out errant cattle is strongly recommended.

Every effort should be made to eliminate leafy spurge from Chokecherry Spring. Because the stand is small, mechanical methods may be a reasonable alternative to herbicide treatment, which could affect native vegetation. Canada thistle, represented by small stands at springs and seeps, should be eliminated as well. Field bindweed poses little threat to native vegetation at JECA, since it occurs only on disturbed sites.

Fire suppression in the Black Hills during white settlement times is thought to have led to the expansion of pine communities at the expense of grasslands 
(Progulske and Sowell 1974). Bock and Bock (1984) showed that periodic burning can eliminate pine seedlings from grasslands and pine savannahs, and thus maintain these vegetation types. A burning program at JECA could be used toward achieving the following goals:

reduction of pine invasion, thus maintaining grassland com munities;

opening up of ponderosa pine communities by increasing the area of grassy openings in ponderosa pine-snowberry communities and expanding the area occupied by ponderosa pine-little bluestem com munities;

reduction of understory cover and accumulated dead material in ponderosa pine-ninebark com munities;

reduction of doghair.

The topic of natural ponderosa pine forest conditions is controversial. Vegetation changes both in space and time in response to factors such as soil type, aspect, climatic change, history (chance) and many others. While fire suppression undoubtedly has contributed to expansion of pine forest in the Black Hills, soils information from the JECA area suggests that the trend is independent of human activity to some degree. The presence of non-forest and relatively-young forest soils (such as the Sawdust and Vanocker) under sizeable stands of pine (often with many individuals well over 100 years old) indicates that the forests developed relatively recently, but before the arrival of the white man (D. Hoeft pers. Comm.). In other words, pine forest expansion in the Black Hills may be in part a natural phenomenon.

A reasonable objective for ponderosa pine management at JECA would be to maintain a mosaic for ponderosa pine communities through periodic burning of some stands, and thinning and removal of accumulated dead material where levels are unsafe for burning. A fire history study is needed to estimate a suitable periodicity for burning. Stands should be sampled before as well as after burns, as the data collected for this mapping project may be too general to detect certain vegetation changes.

\section{Literature Cited}

Bock, J. H. and C. E. Bock. 1984. Effect of fires on woody vegetation in the pine-grassland ecotone of the southern Black Hills. Amer. Midl. Nat. $112: 35-42$.

Hautcooper, W. C., D. J. Ode, J. A. Pearson and G. M. Vandell III. 1985. Rare animals and plants of South Dakota. Prairie Nat. 17:143-165.

Progulske, D. R. and R. H. Sowell 1974. Yellow are, yellow hair, yellow pine. A photographic study of a century of forest ecology. SD Agric. Exp. Sta. Bull. 616:1-169.

Thilenius, J. F. 1971. Vascular plants of the Black Hills of South Dakota and adjacent Wyoming. U.S.D.A. For. Serv. Res. Pap. RM-71:1-43. 